\title{
A Histochemical Study on the Skin of Human Embryo.
}

\author{
Haruo MACHIDA \\ Department of Anatomy, School of Medicine, Keio University, Tokyo, Japan.
}

\section{Introduction}

There are many reports on the histochemistry of the skin of human adult, but only few have been reported on the human embryo. The author made a histochemical survey on the skin of human embryo, paying particular attention to the changes of distribution and reactivity of several enzymes.

\section{Materials and Methods}

Materials used are skin of human embryo from 4 th to 10 th month in development. The skin from the following regions are examined by histochemical procedure ; scalp, eyelid, cheek, lip, breast, back, axilla, external genitalia, perianal region, palm and sole. Paraffin sections of tissues, fixed in Helly's solution, were stained with (a) Heidenhain's iron hematoxylin, (b) Mallory's azan staining and (c) PAS staining. Cytochrome oxidase, succinic dehydrogenase, monoamine oxidase and phosphorylase were demonstrated in frozen sections of unfixed tissues. Other enzymes were studied in frozen sections fixed for 4 hours in $10 \%$ formalin: (1) alkaline phosphatase and acid phosphatase; (2) nonspecific esterase (alpha naphthol esterase and naphthol AS esterase); (3) aminopeptidase ; (4) acetylcholinesterase and butyrylcholinesterase.

\section{Observation}

1) Epidermis: Cytochrome oxidase, succinic dehydrogenase and monoamine oxidase in the embryo 4 months old are concentrated in Malpighian layer. The activity of these three enzymes gradually increase with development. Phosphorylase activity decreases in accordance with the increase of fetal month. Alkaline phosphatase is not observed in epidermis of each fetal month. Acid phosphatase is more strongly stained in stratum spinosum than in stratum basale. Naphthol AS esterase and alpha naphthol esterase are found in Malpighian layer.

2) Pilary System : Reaction of cytochrome oxidase, monoamine oxidase, succinic dehydrogenase and phosphorylase increases in proportion to the advance of fetal month. Acetylcholinesterase-positive nerve endings are in contact with the apex of hair follicle in the 4 th fetal month, hair follicles are encircled with coarse nerve fiber containing acetylcholinesterase. Cholinesterase-positive nerve endings are observed in the hair follicle from 5 th to 10 th fetal month. Alkaline phosphatase is concentrated in the outermost layer of the 
hair primordia and in the apex of hair follicle in 4 th fetal month. Then after, alkaline phosphatase activity in hair follicle gradually becomes weaker and finally in 10 th fetal month, the enzyme reaction is only encountered in the apex of hair follicle. The reaction of acid phosphatase is more intensive in inner root sheeth than in outer one, in every fetal month. The intensity of both acid phosphatase and nonspecific esterase are stationary in the hair follicle from 4 th to 10 th fetal month.

3) Sebaceous Gland: Reaction of cytochrome oxidase, monoamine oxidase and succinic dehydrogenase are stronger in the latter half of fetal life than in the former half of that. Phosphorylase is strongly reactive in the sebaceous gland in 4 th and 5 th fetal month, while activity declines gradually after 6 th fetal month. Acetylcholinesterase-positive fibers are not observed in or around the sebaceous glands in 4 th and 5 th fetal month. The first appearance of cholinesterase-positive nerve fibers around the sebaceous gland is in 6 th fetal month. The sebaceous gland is free of alkaline phosphatase during the whole course of the development. The more the fetal month advances, the more weakly acid phoshatase is stained. Nonspecific esterase is stonger in the peripheral region of sebaceous gland than in the central area.

4) Sweat Gland: Activities of cytochrome oxidase, monoamine oxidase and succinic dehydrogenase, both in eccrine gland and in apocrine glands, increase with the development of human embryo. The reaction of phosphorylase increase in the eccrine glands with the advance of the fetal month. On the contrary, the reaction of phosphorylase in apocrine gland is in inverse proportion to that in eccrine gland. After 5 th fetal month, phosphorylase in both kinds of glands is stronger in the duct than in the secretory portion. Moreover, myoepithelial cells in both kinds of glands are unreactive to phosphorylase reaction. First in 7 th fetal month, the basal cell of eccrine gland gets more activity of phosphorylase than the superficial cell. Moreover, in 8 th fetal month the duct is dotted with strong phosphorylase positive cells which supposed to be the outer layer cells in the adults. In 8 th fetal month, strong phosphorylase-positive non-typical cells are observed only in the secretory portion of apocrine gland. Acetylcholinesterase-positive fibers in 4 th fetal moth come in contact with the apex of primordium of eccrine gland or few fibers already reached eccrine gland. The number of these fibers increase in proportion to the development of embryo. On the contray, apocrine glands from 4 th to 7 th fetal month have no these fibers around them. First in 8 th fetal month, acetylcholinesterase-positive fibers appear around the secretory portion of apocrine gland. No fiber containing cholinesterase is found around the both kinds of glands. Alkaline phosphatase activity in both kinds of glands declines in accordance with the developmental stages. Alkaline phosphatase is reactive along the supposed lumen and the apex of eccrine gland in 4 th fetal moth. Such pattern of the distribution of the activity is observed neither in eccrine gland after 7 th fetal month nor in apocrine gland after 6 th fetal month. Such pattern of the distribution of the activity is observed neither in eccrine gland after 7 th fetal month nor in apocrine gland after 6 th fetal month. 
Moreover, myoepithelial cells of both kinds of glands are unreactive to alkaline phosphatase from 4 th to 10 th fetal month. Acid phosphatase in both kind of glands decreases with the advance of fetal month. The more embryo develops, the more strongly nonspecific esterase is reactive in both kinds of glands. Both naphthol AS esterase and alph naphthol esterase in eccrine glands are more strongly reactive in palm and sole than in another portion of body. Such differences appear first in 5 th fetal month in case of naphthol AS esterase and in 6 th one in case of alpha naphthol esterase.

\section{Discussion}

Human skin was studied in detail histochemically by many authors. But the skin of human embryo was not investigated histochemically in each month and in various portions of body. However both secretory portions of apocrine gland and eccrine gland in adult are discriminated with phosphorylase reaction, both kind of glands in embryo from 4 to 7 months old are unable to be distinguished with that staining procedure. Even apocrine gland in embryo of 10 months old is still reactive to phosphorylase, showing no similarity to the negative results in the adult. Physiological mechamism of sweat secretion in the eccrine gland of palm and sole is different from those over the general body surface. However, the eccrine glands in each portion of body surface are almost similar in the histochemical reaction, with the exception of the distribution of nonspecific esterase which is demonstrated in the eccrine glands of palm and sole but is not found in those of genital body surface. Acetylcholinesterase positive nerve fibers around apocrine glands of the axilla in adult are not observed, but those exceptionally are demonstrated. In most cases, the nerves around the apocrine glands of embryo are unreactive to acetylcholinesterase reaction. But nerve fibers containing specific cholinesterase are observed in the neighborhood of the apocrine gland in such specialized skin area as axilla and perianal portion after 8 th fetal month. It is presumed that the network of the nerve fibers which contain acetylcholinesterase might become looser around the apocrine glands after birth, and finally turned into invisible condition in the adults.

\section{Conclusion}

1) The activity of cytochrome oxidase, monoamine oxidase, succinic dehydrogenase, acetylcholinesterase, naphthol AS esterase and alpha naphthol esterase tends to become inverse in skin and its appendages with the development of embryo.

2) The activity of alkaline and acid phosphatases in the skin decreases in proportion to the advance of the fetal month.

3) The phosphorylase activity become stronger in the eccrine gland and the hair follicle, while decreased in epidermis, sebaceous gland and apocrine gland during the course of the development.

4) Histochemical difference between eccrine glands in palm and that in another portions of body is realized by both naphthol AS esterase and alpha naphthol esterase staining methods. 


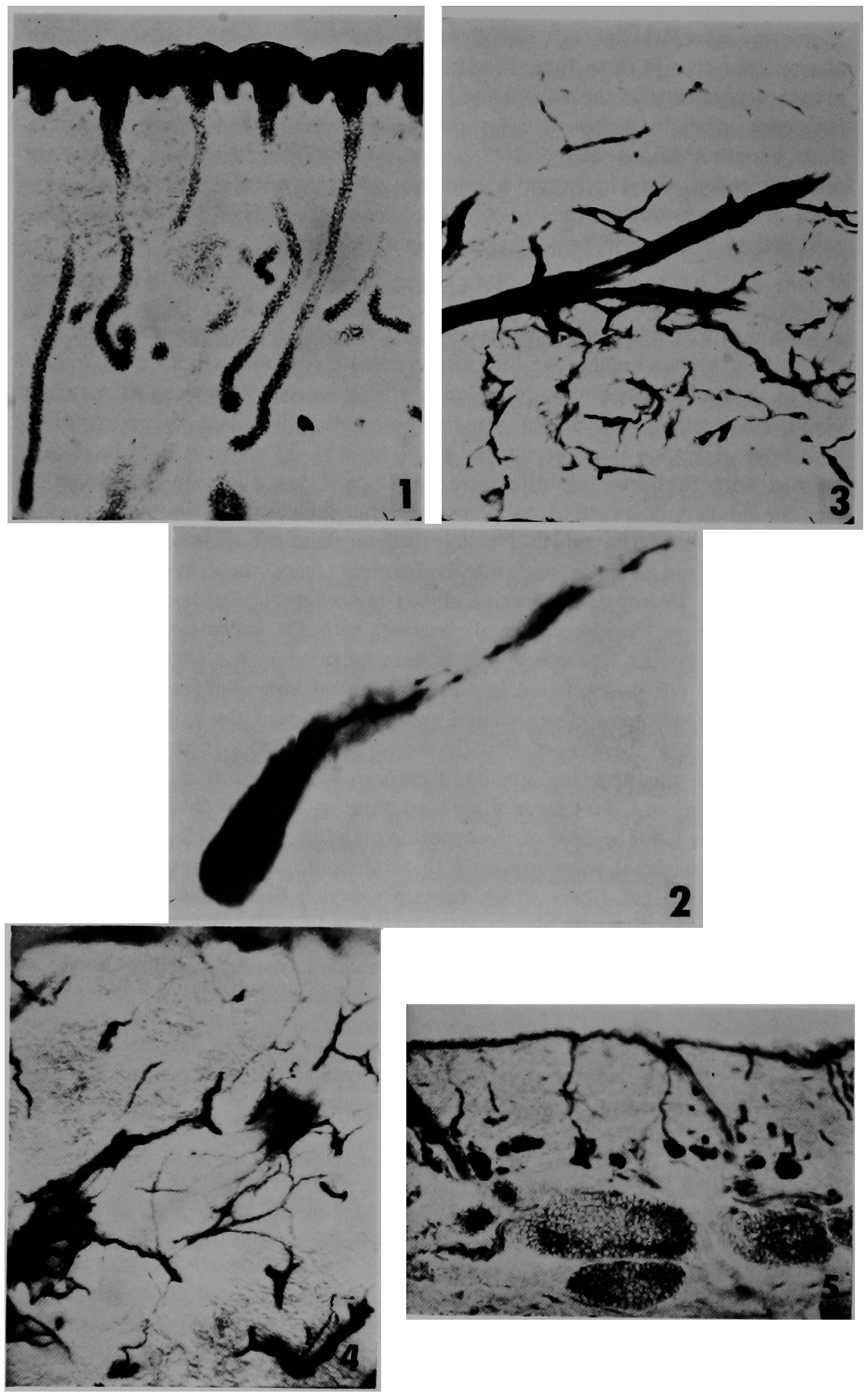




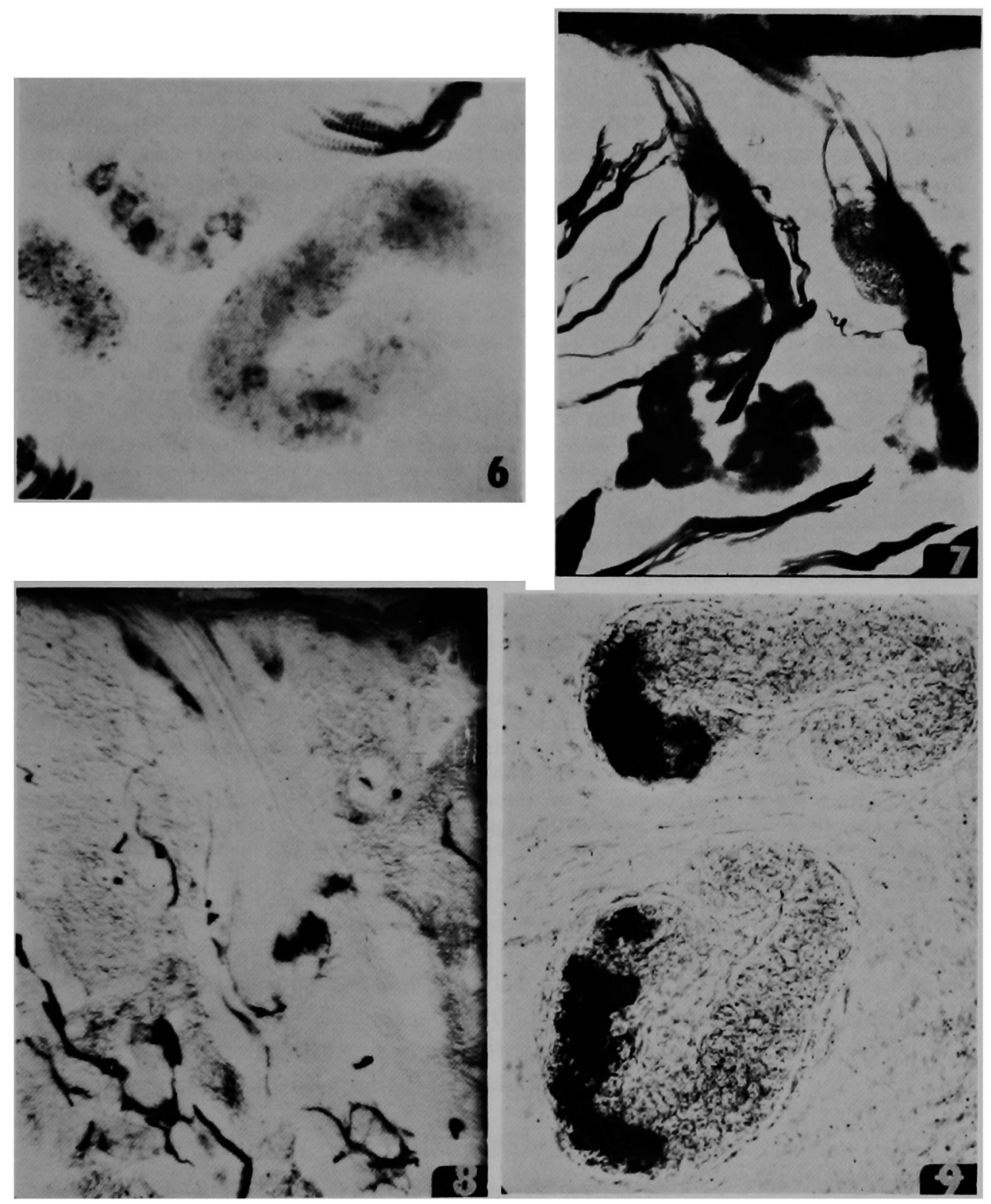

5) Acetylcholinesterase positive nerve fibers are observed around the eccrine gland from 4 th to 10 th fetal month, while those are not encountered around the apocrine gland from 4 th to 7 th fetal month. Nerve fibers containing acetylcholinesterase appear around the apocrine gland first in 8 th fetal month and are wrapt around that till 10 th fetal month.

\section{References}

1) Burstone, M. S. : J. Histochem. Cytochem., 7, 112-122, 1959. 2) Farber, E. and C. D. Louviere : Ibid., 4, 347-356, 1956. 3) Glenner, G. G., H. J. Burtner and G. W. Brown : 
Ibid., 5, 591-600, $1957 . \quad$ 4) Takeuchi, T. and H. Kuriaki : Ibid., 3, 153-160, $1955 . \quad 5$ ) Gomori, G. : Microscopic Histochemistry. Principles and Practice. The University of Chicago Press, Chicago, Illinois, 1952.6 6) Pearse, A, G. E. : Histochemistry, Theoretical and Applied. J. \& A. Churchill, Ltd., London, $1960 . \quad 7)$ Burstone, M. S. and J. E. Folk : J. Histochem. Cytochem., 4, 217-226, $1956 . \quad$ 8) Koelle, G. B. and Friedenwald : Proc. Soc. Exptl. Biol. Med., 70, 617-622, 1949. 9) Montagna, W. : The structure and function of skin. Academic Press Inc., New York, 1956. 10) Montagna, W. : Advances in Biology of skin, vol. 1. Cutaneous Innervation. Pergamon Press Inc., New York, 1960.

\title{
Explanation of Figures
}

1) Skin from the palm of an embryo 5 months old, showing strong monoamine oxidase activities, both in the ridges of the epidermis and in the supposed secretory portions of eccrine glands. $\times 100$

2) Alkaline phosphatase in the eccrine gland from the axilla, the cord region of the gland shows the strong and linear reaction of enzyme in the central portion of the gland. $\times 200$

3) Specific cholinesterase in the nerves of the skin of the palm in the 5 th fetal month. A large nerve trunk in the middle portion and many nerve fibers around the eccrine glands in the lower portion are strongly reactive. $\times 110$

4) Section of the perianal region of an embryo 7 months old, showing the nerve fibers containing specific cholinesterase around the eccrine gland in the left-lower portion and the pseudocholinesterase containing end-organs around the hair follicle in the middle portion. $\times 200$

5) Cytochrome oxidase in the epidermis, the hair follicle, the immature adipose tissue, the eccrine and the apocrine gland of an embryo 7 months old. $\times 45$

6) Phosphorylase in the lip in the 8 th fetal month, showing strong activities both in the basal cells of the eccrine gland and in the myofibrils. $\times 330$

7) Skin from the lip of an embryo 8 months old, treated with the phosphorylase technique. Enzymatic activities are observed in the hair follicle, the myofibril and apocrine gland, while the sebaceous gland is unreactive. $\times 100$

8) Skin from the perianal region of an embryo 8 months old, showing nerve fibers containing specific cholinesterase around the apocrine gland in the right-lower portion and pseudocholinesterase containing end-organs around the hair follicle in the middle portion. $\times 120$

9) The eccrine gland of the palm in 10 th fetal month, treated with naphthol AS esterase technique. Enzymatic activities are demonstrated in the gland cells except the myoepithelial cells. $\times 430$

\section{Histochemical investigation the skin of Macaca fuscata fuscata}

\author{
Toshio Suzuki \\ Department of Anatomy, School of Medicine, Keio University, Tokyo.
}

\section{Preface}

As one of the series of studies on the skin, the author have investigated the distribution and activity of various enzymes of the skin of Macacus fuscata fuscata. There are many reports which were made by Yasuds (1958, 